\title{
Device Labeled for Single Use
}

National Cancer Institute

\section{Source}

National Cancer Institute. Device Labeled for Single Use. NCI Thesaurus. Code C53602.

A device that is intended for one use, or on a single patient during a single procedure

(T itle 21 Chapter 9 Federal Food, Drug and Cosmetic Act). 